\title{
Effect of variety and sulphur on yield and yield components of groundnut
}

\section{Nurezannat $^{1}$, Md Abdur Rahman Sarkar ${ }^{1},{ }^{\natural}$ Md Romij Uddin ${ }^{1}$, Uttam Kumer Sarker ${ }^{1}$, Md Salahuddin Kaysar ${ }^{2}$ and Pikon Kumar Saha ${ }^{3}$}

${ }^{1}$ Department of Agronomy, Bangladesh Agricultural University, Mymensingh-2202, Bangladesh

${ }^{2}$ Upazilla Agriculture Officer, Tarakanda, Mymensingh, Bangladesh

${ }^{3}$ Upazilla Agriculture Officer, Sherpur Sadar, Sherpur, Bangladesh

\begin{tabular}{l}
\hline ARTICLE INFO OPENOAccess \\
\hline Article history: \\
Received : 05 November 2018 \\
Accepted : 09 March 2019 \\
Published: 31 March 2019 \\
\hline
\end{tabular}

Keywords:

Leaf area index, total dry matter, shelling percentage, harvest index and yield

\section{Correspondence:}

Md. Romij Uddin

凶: romijagron@bau.edu.bd

\begin{abstract}
Variety and sulphur play a significant role in the physiological growth and yield of crops such as groundnut. Even so, there has been little information on the application of variety and sulphur in groundnut. Therefore, an experiment was conducted at the Agronomy Field Laboratory, Bangladesh Agricultural University (BAU), Mymensingh to investigate the effect of sulphur on yield and yield components of two groundnut varieties. The experiment comprised two varieties of groundnut viz. BARI Cheenabadam-8 and Bina cheenabadam-6; and five levels of sulphur viz. $0,15,30,45$, and $60 \mathrm{~kg} \mathrm{ha}^{-1}$. The experiment was laid out in a randomized complete block design with three replications. Among the parameters leaf area index $(2.03)$, dry matter plant ${ }^{-1}(50.36 \mathrm{~g})$, number of primary branches plant ${ }^{-1}(10.33$ $\mathrm{cm})$, number of secondary branches plant ${ }^{-1}(9.27 \mathrm{~cm})$, number of pegs plant ${ }^{-1}(46.27)$, number of total pods plant $^{-1}(37.80), 100$-pods weight $(96.82 \mathrm{~g}), 100$ - seeds weight $(46.25 \mathrm{~g})$, shelling percentage $(85.29 \%)$, pod yield $\left(3.13 \mathrm{t} \mathrm{ha}^{-1}\right)$, seed yield $\left(2.67 \mathrm{t} \mathrm{ha}^{-1}\right)$, stover yield $\left(6.84 \mathrm{t} \mathrm{ha}^{-1}\right)$, and harvest index $(31.37 \%)$ were the highest in BARI Cheenabadam-8, when treated with sulphur $60 \mathrm{~kg} \mathrm{ha}^{-1}$. The lowest values of all these parameters were found in Binacheenabadam-6, when no sulphur was applied. This study suggested that BARI Cheenabadam-8 combined with sulphur $60 \mathrm{~kg} \mathrm{ha}^{-1}$ could be applied for obtaining the highest yield of groundnut.
\end{abstract}

(C2019 by authors and BAURES. This work is licensed under the Creative Commons Attribution International License (CC By 4.0).

\section{Introduction}

Groundnut is an important oil-seed crop because its seed contains about 48 to $52 \%$ high quality oil, 25 to $36 \%$ highly digestible protein (Mondal and Wahhab, 2001), $20 \%$ carbohydrates, 5\% fiber and Vitamin B and E which make a substantial contribution to human nutrition. Globally, 50\% of that groundnut is used for oil extraction, $37 \%$ for confectionary use and $12 \%$ for seed purpose. Bangladesh is an oil deficit country. It requires about 446 thousand tons of edible oil annually but it produces only about 187.0 thousand tons mainly from mustard, sesame and groundnut. The deficient is partly met mainly by soybean oil imported from foreign countries which incurs a huge amount of foreign currency to the tune of 3412 million taka annually. To save the foreign currency and to make the country selfsufficient in edible oil, it is extremely necessary to increase the total production of oilseed crops including groundnut either by increasing their per acre yield or by increasing their acreage of cultivation or by a combination of both.

Variety is the most important factor in groundnut production. Use of high yielding variety has been increased remarkably in recent years and the country has almost reached a level of sufficiency in groundnut. Sulphur plays an important role in the metabolism of groundnut plant. It is important for the synthesis of proteins. It helps in biological oxidation-reduction processes. It plays an important role in chlorophyll formation. Sulphur is one of the secondary essential plant nutrient element and it ranks in importance with nitrogen and phosphorus in the formation of protein (Colman, 1996). Bandapadhyay et al., (1998) showed that sulphur application significantly improved the yield and yield attributes of groundnut. The application of sulphur fertilizer in groundnut has been found effective in increasing the yield through increasing the number of pegs and pods plant ${ }^{-1}$, weight of 100-pods, kernel to shell ratio and yield of pod (Bhardwaj and Pathak, 1987). The crop yield depends on the presence of sufficient nutrient in soil and their uptake by plant. The deficiency of NPK and S tremendously affect groundnut production. To overcome this deficiency, fertilizers containing these nutrient elements are to be applied in proper dose. The study was undertaken to evaluate the yield performance of different varieties of groundnut and to optimize dose of sulphur fertilizer for maximum yield of groundnut.

\section{Cite this article}

Nurezannat, Sarkar, M.A.R., Uddin, M.R., Sarker, U.K., Kaysar, M.S. and Saha, P.K.. 2019. Effect of variety and sulphur on yield and yield components of groundnut. Journal of Bangladesh Agricultural University, 17(1): 1-8. https://doi.org/10.3329/jbau.v17i1.40656 


\section{Materials and Methods}

The research work was carried out at the Agronomy Field Laboratory, Bangladesh Agricultural University (BAU), Mymensingh. Geographically the field is located at $24^{\circ} 75^{\prime} \mathrm{N}$ latitude and $90^{\circ} 50^{\prime} \mathrm{E}$ longitude at the elevation of $18 \mathrm{~m}$ above the sea level. The topography of the field was medium high belonging to the Sonatola soil series of grey floodplain soil under the Agro-ecological Zone-9 (AEZ-9) named Old Brahmaputra Floodplain characterized by Non-calcareous Dark Grey Floodplain Soil (FAO and UNDP, 1988). The land was medium high with sandy loam texture and well drained having $\mathrm{pH}$ 5.9. The experiment comprised two varieties of Groundnut /Cheenabadam viz. $\mathrm{V}_{1}$-BARI Cheenabadam-8 and $\mathrm{V}_{2}-$ Binacheenabadam-6 and five levels of sulphur viz. $S_{1}=$ $0 \mathrm{~kg} \mathrm{~S} \mathrm{ha}{ }^{-1}, \mathrm{~S}_{2}=15 \mathrm{~kg} \mathrm{~S} \mathrm{ha}^{-1}, \mathrm{~S}_{3}=30 \mathrm{~kg} \mathrm{~S} \mathrm{ha}^{-1}, \mathrm{~S}_{4}=45$ $\mathrm{kg} \mathrm{S} \mathrm{ha}{ }^{-1}$ and $\mathrm{S}_{5}=60 \mathrm{~kg} \mathrm{~S} \mathrm{ha}^{-1}$. The experiment was laid out following randomized complete block design with 3 replications. The land was ploughed and cross ploughed three times followed by laddering to obtain the desirable tilth.

Urea, muriate of potash (MOP), triple super phosphate (TSP), zinc sulphate and boric acid were applied @ 80 $\mathrm{kg} \mathrm{ha}^{-1}, 140 \mathrm{~kg} \mathrm{ha}^{-1}, 150 \mathrm{~kg} \mathrm{ha}^{-1}, 4.5 \mathrm{~kg} \mathrm{ha}^{-1}, 5.88 \mathrm{~kg}$ $\mathrm{ha}^{-1}$, respectively. Sulphur fertilizer was applied according to experimental treatment. The source of sulphur was gypsum. Entire amount of all the fertilizers were applied at final land preparation. The seeds of groundnut were sown in rows made by hand plough. The distance between row to row was $25 \mathrm{~cm}$ and seed to seed was $10 \mathrm{~cm}$, respectively. Two weedings were done during the study period. No irrigation was given at the early stage of the crop because of presence of sufficient moisture in the field and irrigation was given at the later stage because of deficient of rainfall. Cercospora leaf spot of groundnut was noticed at the flowering stage. For this Bavistin 50 WP was sprayed @ $2 \mathrm{~g} \mathrm{~L}^{-1}$ of water for 2 times at an interval of 10 days.

The harvesting of crop was done at full maturity. The maturity was confirmed by testing the shell that became whitish streaks at the inner side and the testa became brownish color. The weight of pods per plot was taken after properly drying of them in the sun for few days until a constant weight was obtained. The data on crop characters were taken from 5 randomly selected plants from each plot prior to harvest. The sample plants were uprooted carefully with sufficient soil so that the pods were not detached from the plants. Then the harvested plants were washed in running tap water to remove soil and soaked with blotting paper to remove the adhering water on it. The plants were separated into leaves, stems and roots. Total leaf area of individual sample was measured by an electronic leaf area meter (Licor-1300, USA). The components were oven dried at $70^{\circ} \mathrm{C}$ for 48 hours to record constant dry weights. Total dry matter was determined by recording the dry weight of each portion of the plant. The data collected on different parameters were statistically analyzed to obtain the level of significance using the MSTAT-computer package programme developed by Russel (1986). The differences among treatment means were compared by Duncan's New Multiple Range Test (DMRT) at 5\% level of probability (Gomez and Gomez., 1984).

\section{Results and Discussion \\ Leaf area index}

Leaf area index was significantly affected by variety (Table 1). Leaf area index ranged from 1.42 to 1.47 . Higher leaf area index (1.47) was recorded from BARI Cheenabadam-8 than that of Binacheenabadam-6 (1.42). Differences in genetic make- up of the varieties were mainly responsible for this variation in leaf area index. The effect of sulphur on leaf area index was significant (Table 2). It was noted that leaf area index increased progressively with increasing level of sulphur. Leaf area index was the highest (2.02) in $60 \mathrm{~kg} \mathrm{Sha}^{-1}$ followed inorder by $\mathrm{S}_{4}, \mathrm{~S}_{3}$ and $\mathrm{S}_{2}(1.43,1.34$ and 1.26 , respectively). Interaction effect of variety and sulphur on leaf area index was significant (Table 3). The highest leaf area index was recorded from $\mathrm{V}_{1} \times \mathrm{S}_{5}$ (2.03) and the lowest leaf area index was recorded from $\mathrm{V}_{2} \times \mathrm{S}_{1}(1.13)$.

\section{Total dry matter}

Dry matter was significantly affected by variety (Table 1). Dry matter ranged from $43.22 \mathrm{~g}$ to $44.32 \mathrm{~g}$. Higher total dry matter (44.32 g) was recorded from BARI Cheenabadam- 8 than that of Binacheenabadam-6 $(43.22 \mathrm{~g})$. Differences in genetic make-up of the varieties were mainly responsible for this variation in dry matter. The effect of sulphur on dry matter was significant (Table 2). It was noted that dry matter increased progressively with increasing level of sulphur. Dry matter was the highest $(50.14 \mathrm{~g})$ in $60 \mathrm{~kg} \mathrm{~S}^{-1}$ followed in-order by $\mathrm{S}_{4}, \mathrm{~S}_{3}$ and $\mathrm{S}_{2}(45.07 \mathrm{~g}, 43.58 \mathrm{~g}$ and $40.81 \mathrm{~g}$, respectively). The improvement of shoot length, number of primary and secondary branches plant ${ }^{-1}$ and leaf area index were mainly responsible for the increased dry matter in $60 \mathrm{~kg} \mathrm{~S} \mathrm{ha}^{-1}$. Interaction effect of variety and sulphur on dry matter was significant (Table 3). The highest dry matter was recorded from $\mathrm{V}_{1} \times \mathrm{S}_{5}(50.36 \mathrm{~g})$ and the lowest dry matter was recorded from $\mathrm{V}_{2} \times \mathrm{S}_{1}$ (38.84 g)

\section{Number of primary branches plant ${ }^{-1}$}

Number of primary branches plant ${ }^{-1}$ was significantly affected by variety (Table 1). The number of primary branches plant ${ }^{-1}$ ranged from $8.85 \mathrm{~cm}$ to $9.34 \mathrm{~cm}$. Higher number of primary branches plant ${ }^{-1}(9.34 \mathrm{~cm})$ was recorded from BARI Cheenabadam- 8 than that of Binacheenabadam-6 $(8.85 \mathrm{~cm})$. Differences in genetic make-up of the varieties were mainly responsible for this variation in number of primary branches plant ${ }^{-1}$. The effect of sulphur on number of primary branches plant ${ }^{-1}$ was significant (Table 2). Number of primary branches plant $^{-1}$ was the highest $(10.10 \mathrm{~cm})$ in $60 \mathrm{~kg} \mathrm{~S} \mathrm{ha}{ }^{-1}$ followed in-order by $S_{4}, S_{3}$ and $S_{2}(9.67 \mathrm{~cm}, 9.07 \mathrm{~cm}$ and $8.83 \mathrm{~cm}$, respectively). Singh et al. (2003) also found the similar result in terms of effect of sulphur on number of 
primary branches plant ${ }^{-1}$. Interaction effect of variety and sulphur on number of primary branches plant ${ }^{-1}$ was significant (Table 3 ). The highest number of primary branches plant ${ }^{-1}$ was recorded from $\mathrm{V}_{1} \times \mathrm{S}_{5}(10.33 \mathrm{~cm})$ and the lowest number of primary branches plant $^{-1}$ was recorded from $\mathrm{V}_{2} \times \mathrm{S}_{1}(7.73 \mathrm{~cm})$.

Table 1. Effect of variety on the studied crop characteristics of groundnut

\begin{tabular}{|c|c|c|c|c|c|c|c|c|c|c|}
\hline $\begin{array}{c}\text { Variety } \\
\text { (V) }\end{array}$ & $\begin{array}{c}\text { Leaf } \\
\text { area } \\
\text { index } \\
\end{array}$ & $\begin{array}{c}\text { Dry } \\
\text { matter } \\
\left(\text { g plant }^{-1}\right) \\
\end{array}$ & $\begin{array}{c}\text { Primary } \\
\text { branches } \\
\text { plant }^{-1}\end{array}$ & $\begin{array}{c}\text { Secondary } \\
\text { branches } \\
\text { plant }^{-1}\end{array}$ & $\begin{array}{c}\text { Number } \\
\text { of pegs } \\
\text { plant }^{-1} \\
\end{array}$ & $\begin{array}{c}\text { 100-pods } \\
\text { weight } \\
\text { (g) } \\
\end{array}$ & $\begin{array}{c}\text { 100-seeds } \\
\text { weight } \\
\text { (g) }\end{array}$ & $\begin{array}{c}\begin{array}{c}\text { Seed } \\
\text { yield } \\
\left(\mathrm{t} \mathrm{ha}^{-1}\right)\end{array} \\
\end{array}$ & $\begin{array}{c}\text { Stover } \\
\text { yield } \\
\left(\mathbf{t ~ h a}^{-1}\right) \\
\end{array}$ & $\begin{array}{c}\text { Harvest } \\
\text { index }(\%)\end{array}$ \\
\hline $\mathrm{V}_{1}$ & $1.47 \mathrm{a}$ & $44.32 \mathrm{a}$ & $9.34 \mathrm{a}$ & $7.35 \mathrm{a}$ & $42.87 \mathrm{a}$ & $87.96 \mathrm{a}$ & $43.66 \mathrm{a}$ & $2.22 \mathrm{a}$ & $6.29 \mathrm{a}$ & $30.62 \mathrm{a}$ \\
\hline $\mathrm{V}_{2}$ & $1.42 \mathrm{~b}$ & $43.22 \mathrm{~b}$ & $8.85 \mathrm{~b}$ & & $38.43 \mathrm{~b}$ & $82.72 \mathrm{~b}$ & $42.58 \mathrm{~b}$ & $2.01 \mathrm{~b}$ & $6.08 \mathrm{~b}$ & $30.01 \mathrm{~b}$ \\
\hline Level of & $* *$ & $* *$ & ** & ** & $* *$ & ** & ** & ** & ** & $* *$ \\
\hline $\mathrm{CV}(\%)$ & 1.71 & 1.46 & 2.06 & 4.58 & 1.35 & 1.22 & 1.45 & 1.45 & 1.34 & 1.01 \\
\hline
\end{tabular}

In a column, figures with same letters or without letter do not differ significantly whereas figures with dissimilar letter differ significantly as per Duncan's New Multiple Range Test (DMRT). $\mathrm{V}_{1}=$ BARI Cheenabadam-8, $\mathrm{V}_{2}=$ BINA Cheenabadam-6, $* *=$ Significant at $1 \%$ level of probability.

Table 2. Effect of sulphur on the studied crop characteristics of groundnut

\begin{tabular}{|c|c|c|c|c|c|c|c|c|c|c|}
\hline $\begin{array}{c}\text { Sulphur } \\
\text { doses }\end{array}$ & $\begin{array}{c}\text { Leaf } \\
\text { area } \\
\text { index } \\
\end{array}$ & $\begin{array}{c}\text { Dry } \\
\text { matter } \\
\left(\text { g plant }^{-1}\right)\end{array}$ & $\begin{array}{c}\text { Primary } \\
\text { branches } \\
\text { plant }^{-1}\end{array}$ & $\begin{array}{c}\text { Secondary } \\
\text { branches } \\
\text { plant }^{-1}\end{array}$ & $\begin{array}{c}\text { Number } \\
\text { of pegs } \\
\text { plant }^{-1}\end{array}$ & $\begin{array}{c}\text { 100-pods } \\
\text { weight } \\
(\mathrm{g}) \\
\end{array}$ & $\begin{array}{c}\text { 100-seeds } \\
\text { weight } \\
\text { (g) }\end{array}$ & $\begin{array}{c}\text { Seed } \\
\text { yield } \\
\left(\mathrm{t} \mathrm{ha}^{-1}\right) \\
\end{array}$ & $\begin{array}{c}\text { Stover } \\
\text { yield } \\
\left(\mathrm{t} \mathrm{ha}^{-1}\right) \\
\end{array}$ & $\begin{array}{c}\text { Harvest } \\
\text { index } \\
(\%)\end{array}$ \\
\hline $\mathrm{S}_{1}$ & $1.20 \mathrm{e}$ & $39.24 \mathrm{e}$ & $7.83 \mathrm{e}$ & $4.74 \mathrm{~d}$ & $34.57 \mathrm{e}$ & $79.69 \mathrm{e}$ & $41.01 \mathrm{~d}$ & $1.57 \mathrm{e}$ & $5.50 \mathrm{e}$ & $29.11 \mathrm{~d}$ \\
\hline $\mathrm{S}_{2}$ & $1.26 \mathrm{~d}$ & $40.81 \mathrm{~d}$ & $8.83 \mathrm{~d}$ & $6.40 \mathrm{c}$ & $39.87 \mathrm{~d}$ & $81.99 \mathrm{~d}$ & $41.72 \mathrm{~d}$ & $1.90 \mathrm{~d}$ & $5.84 \mathrm{~d}$ & $29.58 \mathrm{c}$ \\
\hline $\mathrm{S}_{3}$ & $1.34 \mathrm{c}$ & $43.58 \mathrm{c}$ & $9.07 \mathrm{c}$ & $6.77 \mathrm{c}$ & $41.70 \mathrm{c}$ & $84.14 \mathrm{c}$ & $43.08 \mathrm{c}$ & $2.17 \mathrm{c}$ & $6.36 \mathrm{c}$ & $30.13 \mathrm{~b}$ \\
\hline $\mathrm{S}_{4}$ & $1.43 \mathrm{~b}$ & $45.07 \mathrm{~b}$ & $9.67 \mathrm{~b}$ & $7.23 \mathrm{~b}$ & $42.63 \mathrm{~b}$ & $87.19 \mathrm{~b}$ & $44.37 \mathrm{~b}$ & $2.37 \mathrm{~b}$ & $6.48 \mathrm{~b}$ & $31.20 \mathrm{a}$ \\
\hline $\mathrm{S}_{5}$ & $2.02 \mathrm{a}$ & $50.14 \mathrm{a}$ & $10.10 \mathrm{a}$ & $8.94 \mathrm{a}$ & $44.47 \mathrm{a}$ & $93.67 \mathrm{a}$ & $45.43 \mathrm{a}$ & $2.58 \mathrm{a}$ & $6.74 \mathrm{a}$ & $31.24 \mathrm{a}$ \\
\hline Level of sig. & $* *$ & $* *$ & $* *$ & $* *$ & $* *$ & $* *$ & $* *$ & $* *$ & $* *$ & $* *$ \\
\hline $\mathrm{CV}(\%)$ & 1.71 & 1.46 & 2.06 & 4.58 & 1.35 & 1.22 & 1.45 & 1.45 & 1.34 & 1.01 \\
\hline
\end{tabular}

In a column, figures with same letters or without letter do not differ significantly whereas figures with dissimilar letter differ significantly as per

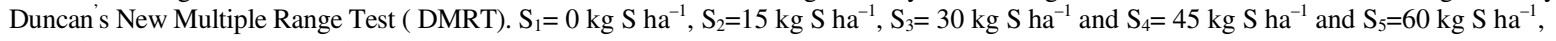

$* *=$ Significant at $1 \%$ level of probability.

Table 3. Interaction effect of variety and sulphur on the studied crop characteristics of groundnut

\begin{tabular}{|c|c|c|c|c|c|c|c|c|c|c|c|c|c|}
\hline $\begin{array}{c}\text { Interaction } \\
(\mathbf{V} \times \mathbf{S})\end{array}$ & $\begin{array}{c}\text { Leaf } \\
\text { area } \\
\text { index }\end{array}$ & $\begin{array}{c}\text { Dry } \\
\text { matter }_{\left(\text {g plant }^{-1}\right)}\end{array}$ & $\begin{array}{c}\text { Primary } \\
\text { branches } \\
\text { plant }^{-1}\end{array}$ & $\begin{array}{c}\text { Secondary } \\
\text { branches } \\
\text { plant }^{-1}\end{array}$ & $\begin{array}{c}\text { Number } \\
\text { of pegs } \\
\text { plant }^{-1}\end{array}$ & $\begin{array}{c}\text { Number } \\
\text { of total } \\
\text { pods } \\
\text { plant }^{-1}\end{array}$ & $\begin{array}{c}\text { 100-pods } \\
\text { weight } \\
\text { (g) }\end{array}$ & $\begin{array}{c}\text { 100-seeds } \\
\text { weight } \\
\text { (g) }\end{array}$ & $\begin{array}{c}\text { Shelling } \\
\text { percentage }\end{array}$ & $\begin{array}{c}\text { Pod } \\
\text { yield } \\
\left(\mathrm{t} \mathrm{ha}^{-1}\right)\end{array}$ & $\begin{array}{c}\text { Seed } \\
\text { yield } \\
\left(\mathrm{t} \mathrm{ha}^{-1}\right)\end{array}$ & $\begin{array}{c}\text { Stover } \\
\text { yield } \\
\left(\mathrm{t} \mathrm{ha}^{-1}\right)\end{array}$ & $\begin{array}{c}\text { Harvest } \\
\text { index } \\
(\%)\end{array}$ \\
\hline $\mathrm{V}_{1} \times \mathrm{S}_{1}$ & 7 ef & & & & & $28.46 \mathrm{e}$ & & & & & & & \\
\hline $\mathrm{V}_{1} \times \mathrm{S}_{2}$ & 7 ef & & & & & & & & & & & & \\
\hline $\mathrm{V}_{1} \times \mathrm{S}_{3}$ & $1.36 \mathrm{~cd}$ & 1.6 & & & & & & & & & & & \\
\hline $\mathrm{V}_{1} \times \mathrm{S}_{4}$ & $1.44 \mathrm{~b}$ & $45.08 \mathrm{~b}$ & $10.20 \mathrm{a}$ & & $44.67 \mathrm{~b}$ & $33.47 \mathrm{~b}$ & & & & $2.97 \mathrm{~b}$ & $2.41 \mathrm{c}$ & & $5 \mathrm{a}$ \\
\hline $\mathrm{V}_{1} \times \mathrm{S}_{5}$ & $2.03 \mathrm{a}$ & $50.36 \mathrm{a}$ & 1023 & & $46.27 \mathrm{a}$ & $37.80 \mathrm{a}$ & & & & $3.13 \mathrm{a}$ & $2.67 \mathrm{a}$ & & $37 \mathrm{a}$ \\
\hline $\mathrm{V}_{2} \times \mathrm{S}_{1}$ & $1.13 \mathrm{~g}$ & $38.84 \mathrm{~d}$ & & & & 23.4 & & & 64 & $2.08 \mathrm{~g}$ & $1.35 \mathrm{i}$ & & $28 \mathrm{~d}$ \\
\hline $\mathrm{V}_{2} \times \mathrm{S}_{2}$ & $1.25 \mathrm{f}$ & $39.76 \mathrm{~d}$ & & & $37.87 \mathrm{f}$ & $26.53 \mathrm{f}$ & 79. & & & 2.3 & & & $3 \mathrm{c}$ \\
\hline $\mathrm{V}_{2} \times \mathrm{S}_{3}$ & $1.32 \mathrm{de}$ & $42.52 \mathrm{c}$ & de & & $39.07 \mathrm{e}$ & $27.81 \mathrm{e}$ & & & & $2.67 \mathrm{~d}$ & 2. & & $94 \mathrm{~b}$ \\
\hline $\mathrm{V}_{2} \times \mathrm{S}_{4}$ & $1.41 b c$ & $45.06 \mathrm{~b}$ & & & & $28.74 \mathrm{e}$ & & & & $2.91 \mathrm{bc}$ & 2. & $6.46 \mathrm{c}$ & $55 \mathrm{a}$ \\
\hline $\mathrm{U} \times \mathrm{C}$ & $2.00 \mathrm{a}$ & $49.92 \mathrm{a}$ & U & $8.60 \mathrm{~b}$ & $7 \mathrm{c}$ & $3 \mathrm{c}$ & b & b & $\mathrm{b}$ & $2.99 \mathrm{ab}$ & $2.49 \mathrm{~b}$ & $6.64 \mathrm{~b}$ & $11 \mathrm{a}$ \\
\hline $\begin{array}{r}\text { Level of } \\
\text { significan }\end{array}$ & $*$ & * & ** & $*$ & $*$ & $* *$ & ** & * & . & $*$ & $* *$ & $*$ & $* *$ \\
\hline $\mathrm{CV}(\%)$ & 1.71 & 1.46 & 2.06 & 4.58 & 1.35 & 2.95 & 1.22 & 1.45 & 0.41 & 2.79 & 1.45 & 1.34 & 1.01 \\
\hline
\end{tabular}

In a column, figures with same letters or without letter do not differ significantly whereas figures with dissimilar letter differ significantly as per Duncan's New Multiple Range Test (DMRT).

$*=$ Significant at $5 \%$ level of probability, $* *=$ Significant at $1 \%$ level of probability, NS= Not significant.

Number of secondary branches plant ${ }^{-1}$

Number of secondary branches plant ${ }^{-1}$ was significantly affected by variety (Table 1 ). The number of secondary branches plant ${ }^{-1}$ ranged from $6.28 \mathrm{~cm}$ to $7.35 \mathrm{~cm}$. Higher number of secondary branches plant ${ }^{-1}(7.35 \mathrm{~cm})$ was recorded from BARI Cheenabadam- 8 than that of Binacheenabadam-6 $(6.28 \mathrm{~cm})$. Differences in genetic make-up of the varieties were mainly responsible for this variation in number of secondary branches plant ${ }^{-1}$. The effect of sulphur on number of secondary branches plant $^{-1}$ was significant (Table 2). Number of secondary branches plant ${ }^{-1}$ was the highest $(8.94 \mathrm{~cm})$ in $60 \mathrm{~kg} \mathrm{~S}$ $\mathrm{ha}^{-1}$ followed in-order by $\mathrm{S}_{4}, \mathrm{~S}_{3}$ and $\mathrm{S}_{2}(7.23 \mathrm{~cm}, 6.77$ $\mathrm{cm}$ and $6.40 \mathrm{~cm}$, respectively). Interaction effect of variety and sulphur on number of secondary branches plant $^{-1}$ was significant (Table 3). The highest number of secondary branches plant ${ }^{-1}$ was recorded from $\mathrm{V}_{1} \times \mathrm{S}_{5}$ $(9.27 \mathrm{~cm})$ and the lowest number of secondary branches plant ${ }^{-1}$ was recorded from $V_{2} \times S_{1}(3.87 \mathrm{~cm})$

\section{Number of pegs plant ${ }^{-1}$}

Number of pegs plant ${ }^{-1}$ was significantly affected by variety (Table 1). The number of pegs plant ${ }^{-1}$ ranged from 38.43 to 42.47 . Higher number of pegs plant ${ }^{-1}$ (42.87) was recorded from BARI Cheenabadam- 8 than that of Binacheenabadam-6 (38.43) Differences in genetic make- up of the varieties was mainly responsible for this 
variation in number of pegs plant ${ }^{-1}$. The effect of sulphur on number of pegs plant ${ }^{-1}$ was significant (Table 2). It was noted that number of pegs plant ${ }^{-1}$ increased progressively with increasing level of sulphur. Number of pegs plant ${ }^{-1}$ was the highest (44.47) in $60 \mathrm{~kg}$ $\mathrm{S} \mathrm{ha}^{-1}$ followed in-order by $\mathrm{S}_{4}, \mathrm{~S}_{3}$ and $\mathrm{S}_{2}(42.63,41.70$ and 39.87 , respectively). They observed that number of pegs plant ${ }^{-1}$ was the highest in sulphur a level of $27 \mathrm{ppm}$. Interaction effect of variety and sulphur on number of pegs plant ${ }^{-1}$ was significant (Table 3). The highest number of pegs plant ${ }^{-1}$ was recorded from $\mathrm{V}_{1} \times \mathrm{S}_{5}$ (46.27) and the lowest number of pegs plant ${ }^{-1}$ was recorded from $\mathrm{V}_{2} \times \mathrm{S}_{1}$ (31.93).

\section{Number of total pods plant ${ }^{-1}$}

Number of total pods plant ${ }^{-1}$ was significantly affected by variety (Fig. 1). The number of total pods ranged from 27.70 to 32.16 . Higher number of total pods plant ${ }^{-1}$ (32.16) was recorded from BARI Cheenabadam-8 than that of Binacheenabadam-6 (27.70). The effect of sulphur on number of total pods plant ${ }^{-1}$ was significant (Fig. 2). Number of total pods plant ${ }^{-1}$ was the highest (34.87) in $60 \mathrm{~kg} \mathrm{~S} \mathrm{ha}^{-1}$ followed in-order by $\mathrm{S}_{4}, \mathrm{~S}_{3}$ and $\mathrm{S}_{2}$ (31.10, 29.50 and 28.20, respectively). The improvement of mature pods, immature pods and developing pods plant $^{-1}$ were mainly responsible for the increased total pods in $60 \mathrm{~kg} \mathrm{~S} \mathrm{ha}^{-1}$. Interaction effect of variety and sulphur on number of total pods plant ${ }^{-1}$ was significant (Table 3). The highest number of total pods plant ${ }^{-1}$ was recorded from $\mathrm{V}_{1} \times \mathrm{S}_{5}$ (37.80) and the lowest number of total pods plant ${ }^{-1}$ was recorded from $V_{2} \times S_{1}(23.47)$.

\section{0-pods weight}

The effect of variety on 100-pods weight was significant (Table 1). Higher 100-pods weight (87.96 g) was recorded from BARI Cheenabadam- 8 than that of Binac heenabadam-6 (82.72 g). Differences in genetic make-up of the varieties were mainly responsible for this variation in 100-pods weight. The effect of sulphur on 100-pods weight was significant (Table 2). 100-pods weight was the highest $(93.67 \mathrm{~g})$ in $60 \mathrm{~kg} \mathrm{~S}^{-1}$ followed in-order by $\mathrm{S}_{4}, \mathrm{~S}_{3}$ and $\mathrm{S}_{2}(87.19 \mathrm{~g}, 84.14 \mathrm{~g}$ and $81.99 \mathrm{~g}$, respectively). The improvement of pod yield was mainly responsible for the increased of 100-pods weight in 60 $\mathrm{kg} \mathrm{S} \mathrm{ha}{ }^{-1}$. Bhardwaj and Pathak et al. (1987) also found the similar result in terms of effect of sulphur on 100-pods weight. They observed that 100 -pods weight was the highest in sulphur a level of $27 \mathrm{ppm}$. Interaction effect of variety and sulphur on 100-pods weight was significant (Table 3). 100-pods weight was the highest $(96.82 \mathrm{~g}$ ) at $\mathrm{V}_{1} \times \mathrm{S}_{5}$ and the lowest (78.46 g) one was found at $\mathrm{V}_{2} \times \mathrm{S}_{1}$.

\section{0-Seeds weight}

The effect of variety on 100-seeds weight was significant (Table 1). Higher number of 100-seeds weight plant $^{-1}(43.66 \mathrm{~g})$ was recorded from BARI Cheenabadam-8 than that of BINA Cheenabadam-6 (42.58 g). Differences in genetic make-up of the varieties were mainly responsible for this variation in 100-seeds weight. The effect of sulphur on 100-seeds weight was significant (Table 2). It was noted that seeds weight increased progressively with increasing level of sulphur. 100 -seeds weight was the highest $(45.43 \mathrm{~g})$ in $60 \mathrm{~kg} \mathrm{~S}$ $\mathrm{ha}^{-1}$ followed in-order by $\mathrm{S}_{4}, \mathrm{~S}_{3}$ and $\mathrm{S}_{2}(44.37 \mathrm{~g}, 43.08 \mathrm{~g}$ and $41.72 \mathrm{~g}$, respectively). Interaction effect of variety and sulphur on 100-seeds weight was significant (Table 3). 100-seeds weight was the highest $(46.25 \mathrm{~g})$ at $\mathrm{V}_{1} \times \mathrm{S}_{5}$ and the lowest (40.79g) one was found at $V_{2} \times S_{1}$.

\section{Shelling percentage}

The effect of variety on shelling percentage was significant (Fig. 3). Higher number of shelling percentage $(79.91 \%)$ was recorded from BARI Cheenabadam-8 than that of BINA Cheenabadam-6 $(77.27 \%)$. The effect of sulphur on shelling percentage was significant (Fig. 4). Shelling percentage was the highest $(84.14 \%)$ in $60 \mathrm{~kg} \mathrm{~S}^{-1}$ followed in-order by $\mathrm{S}_{4}, \quad \mathrm{~S}_{3}$ and $\mathrm{S}_{2} \quad(80.60 \%, 79.14 \%$ and $77.39 \%$, respectively). The improvement of seed yield and pod yield were mainly responsible for the increased shelling percentage in $60 \mathrm{~kg} \mathrm{~S} \mathrm{ha}^{-1}$. Chaubey et al., (2000) also found the similar result in terms of effect of sulphur on shelling percentage. Interaction effect of variety and sulphur on shelling percentage was significant (Table 3 ). Shelling percentage was the highest $(85.29 \%)$ at $\mathrm{V}_{1} \times \mathrm{S}_{5}$ and the lowest $(64.64 \%)$ one was found at $\mathrm{V}_{2} \times \mathrm{S}_{1}$.

\section{Pod yield}

The effect of variety on pod yield was significant (Fig.5). Higher pod yield $\left(2.78 \mathrm{t} \mathrm{ha}^{-1}\right)$ was recorded from BARI Cheenabadam-8 than that of Binacheenabadam-6 (2.61 t $\left.\mathrm{ha}^{-1}\right)$. The effect of sulphur on pod yield was significant (Fig. 6). Pod yield was the highest $\left(3.06 \mathrm{t} \mathrm{ha}^{-1}\right)$ in $60 \mathrm{~kg} \mathrm{~S}$ $\mathrm{ha}^{-1}$ followed in-order by $\mathrm{S}_{4}, \mathrm{~S}_{3}$ and $\mathrm{S}_{2}\left(2.94 \mathrm{tha}^{-1}, 2.74 \mathrm{t}\right.$ $\mathrm{ha}^{-1}$ and $2.46 \mathrm{tha}^{-1}$, respectively. The improvement of 100pods weight, 100-seeds weight, shelling percentage and seed yield were mainly responsible for the increased pod yield in $60 \mathrm{~kg} \mathrm{~S} \mathrm{ha}^{-1}$. Dimreej et al. (1993) also found the similar result in terms of effect of sulphur on pod yield. They observed that pod yield was the highest in the sulphur@ $@ 45 \mathrm{~kg} \mathrm{ha}^{-1}$ through gypsum. Interaction effect of variety and sulphur on pod yield was significant (Table 3). Pod yield was the highest $\left(3.13 \mathrm{tha}^{-1}\right)$ at $\mathrm{V}_{1} \times$ $\mathrm{S}_{5}$ and the lowest $\left(2.08 \mathrm{tha}^{-1}\right)$ one was found at $\mathrm{V}_{2} \times \mathrm{S}_{1}$.

\section{Seed yield}

The effect of variety on seed yield was significant (Table 1). Higher seed yield $\left(2.22 \mathrm{t} \mathrm{ha}^{-1}\right)$ was recorded from BARI Cheenabadam-8 than that of BINA Cheenabadam-6 $\left(2.01 \mathrm{t} \mathrm{ha}^{-1}\right)$. The effect of sulphur on seed yield was significant (Table 2). Seed yield was the highest $\left(2.58 \mathrm{t} \mathrm{ha}^{-1}\right)$ in $60 \mathrm{~kg} \mathrm{~S} h a^{-1}$ followed in-order by $\mathrm{S}_{4}, \mathrm{~S}_{3}$ and $\mathrm{S}_{2}\left(2.37 \mathrm{t} \mathrm{ha}^{-1}, 2.17 \mathrm{tha}^{-1}\right.$ and $1.90 \mathrm{t} \mathrm{ha}^{-1}$, respectively). The improvement of pod yield, 100-seeds weight and 100-pods weight was mainly responsible for the increased seed yield in $60 \mathrm{~kg} \mathrm{ha}^{-1}$. Interaction effect of variety and sulphur on seed yield was significant (Table 3). Seed yield was the highest $\left(2.67 \mathrm{tha}^{-1}\right)$ at $\mathrm{V}_{1} \times$ $\mathrm{S}_{5}$ and the lowest $\left(1.37 \mathrm{tha}^{-1}\right)$ one was found at $\mathrm{V}_{2} \times \mathrm{S}_{1}$. 


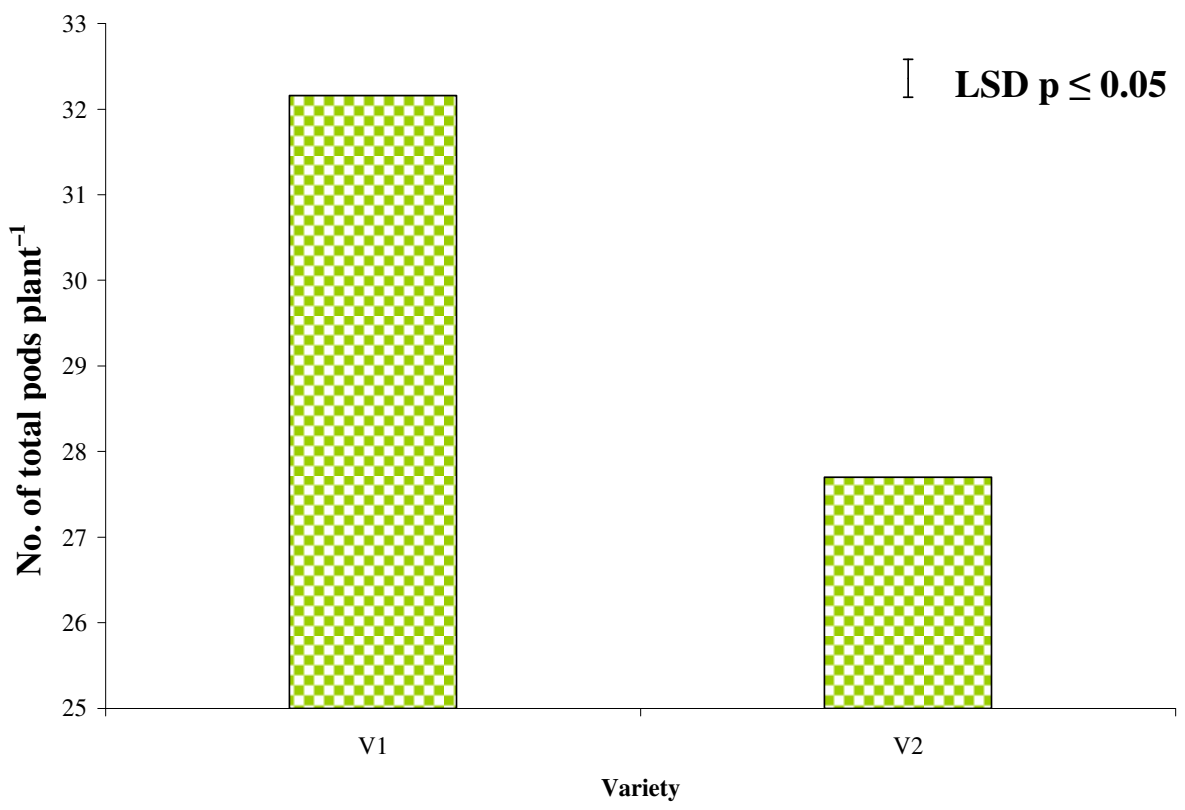

Fig 1. Effect of variety on number of total pods plant ${ }^{-1}$ of groundnut $\mathrm{V}_{1}=$ BARI Cheenabadam- $8, \mathrm{~V}_{2}=$ Binacheenabadam -6 .

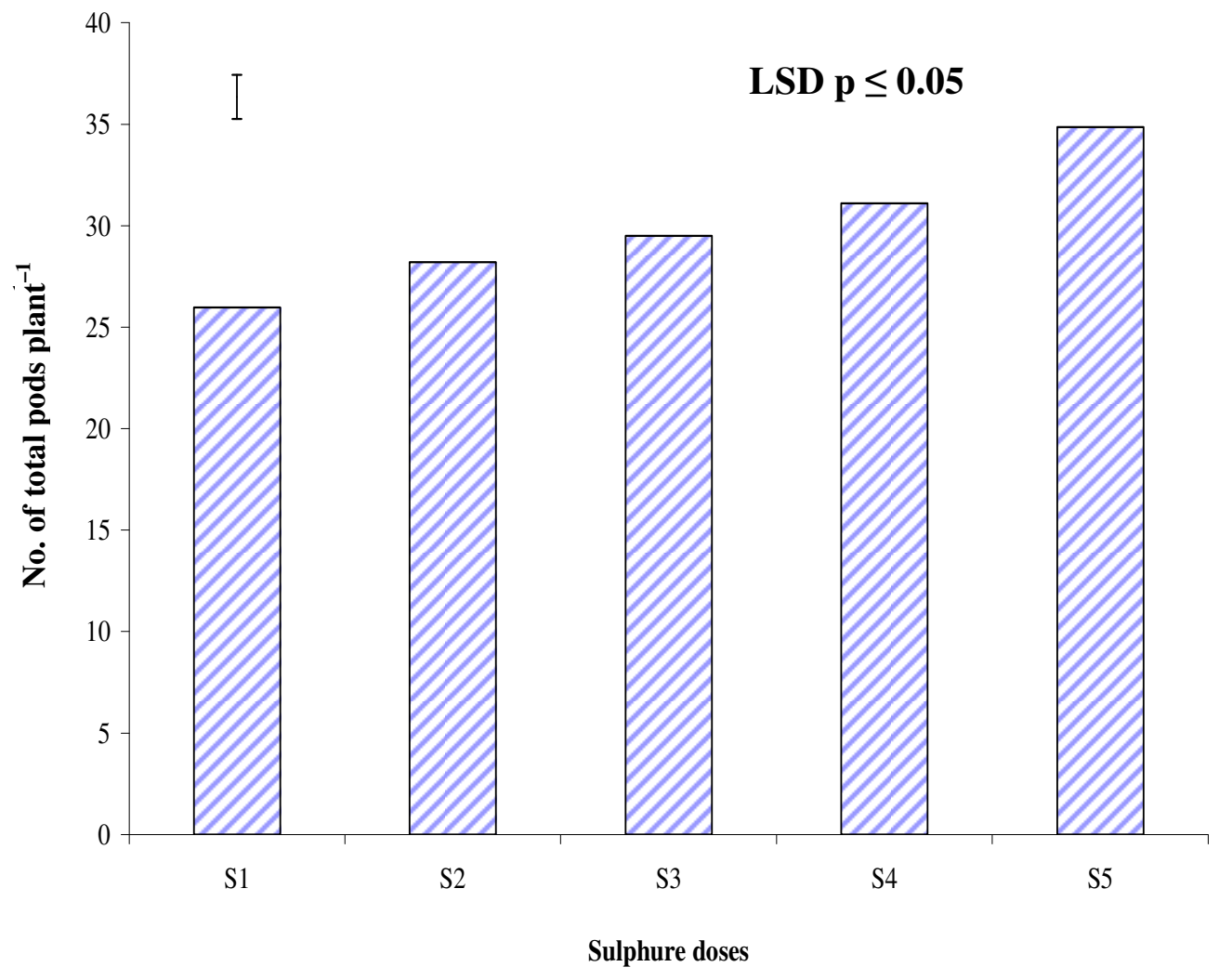

Fig 2. Effect of sulphur on number of total pods plant ${ }^{-1}$ of groundnut $\mathrm{S}_{1}=0 \mathrm{~kg} \mathrm{Sha}^{-1}, \mathrm{~S}_{2}=15 \mathrm{~kg} \mathrm{Sha}^{-1}, \mathrm{~S}_{3}=30 \mathrm{~kg} \mathrm{Sha}^{-1}, \mathrm{~S}_{4}=45 \mathrm{~kg} \mathrm{~S} \mathrm{ha}^{-1}$ and $\mathrm{S}_{5}=60 \mathrm{~kg} \mathrm{Sha}^{-1}$ 


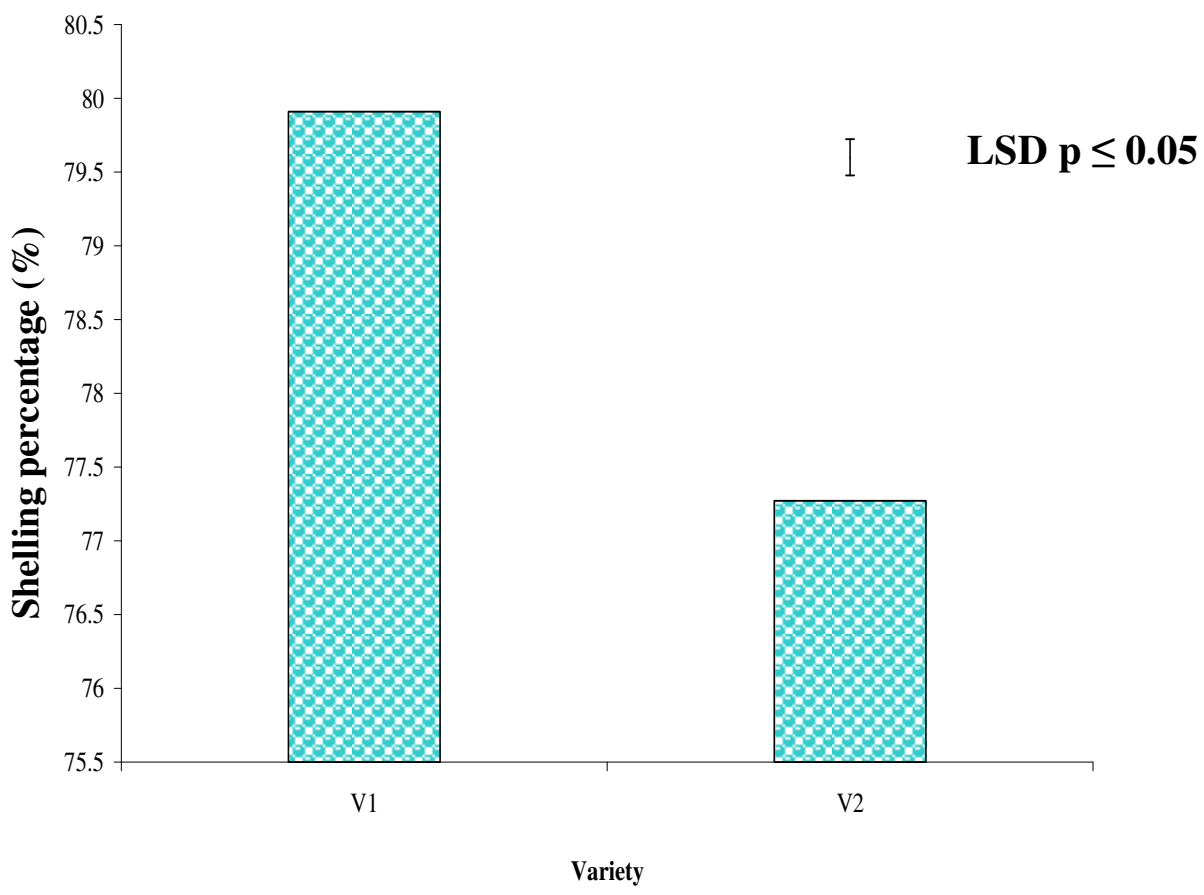

Fig. 3. Effect of variety on shelling percentage of groundnut $\mathrm{V}_{1}=$ BARI Cheenabadam $-8, \mathrm{~V}_{2}=$ Binacheenabadam -6 .

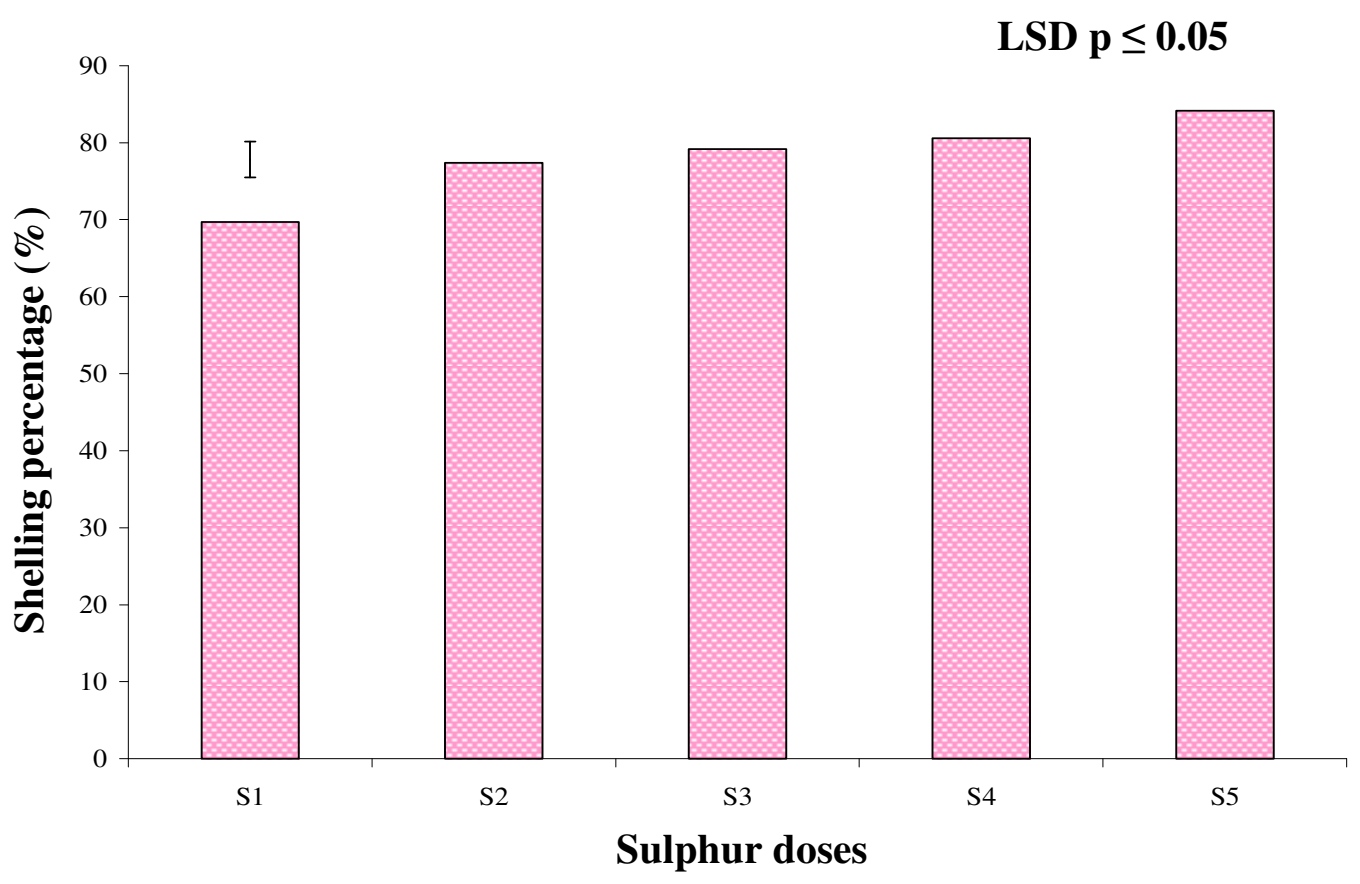

Fig. 4. Effect of sulphur on shelling percentage of groundnut

$\mathrm{S}_{1}=0 \mathrm{~kg} \mathrm{~S} \mathrm{ha}^{-1}, \mathrm{~S}_{2}=15 \mathrm{~kg} \mathrm{Sha}^{-1}, \mathrm{~S}_{3}=30 \mathrm{~kg} \mathrm{~S} \mathrm{ha}^{-1}, \mathrm{~S}_{4}=45 \mathrm{~kg} \mathrm{~S} \mathrm{ha}^{-1}$ and $\mathrm{S}_{5}=60 \mathrm{~kg} \mathrm{~S} \mathrm{ha}^{-1}$ 


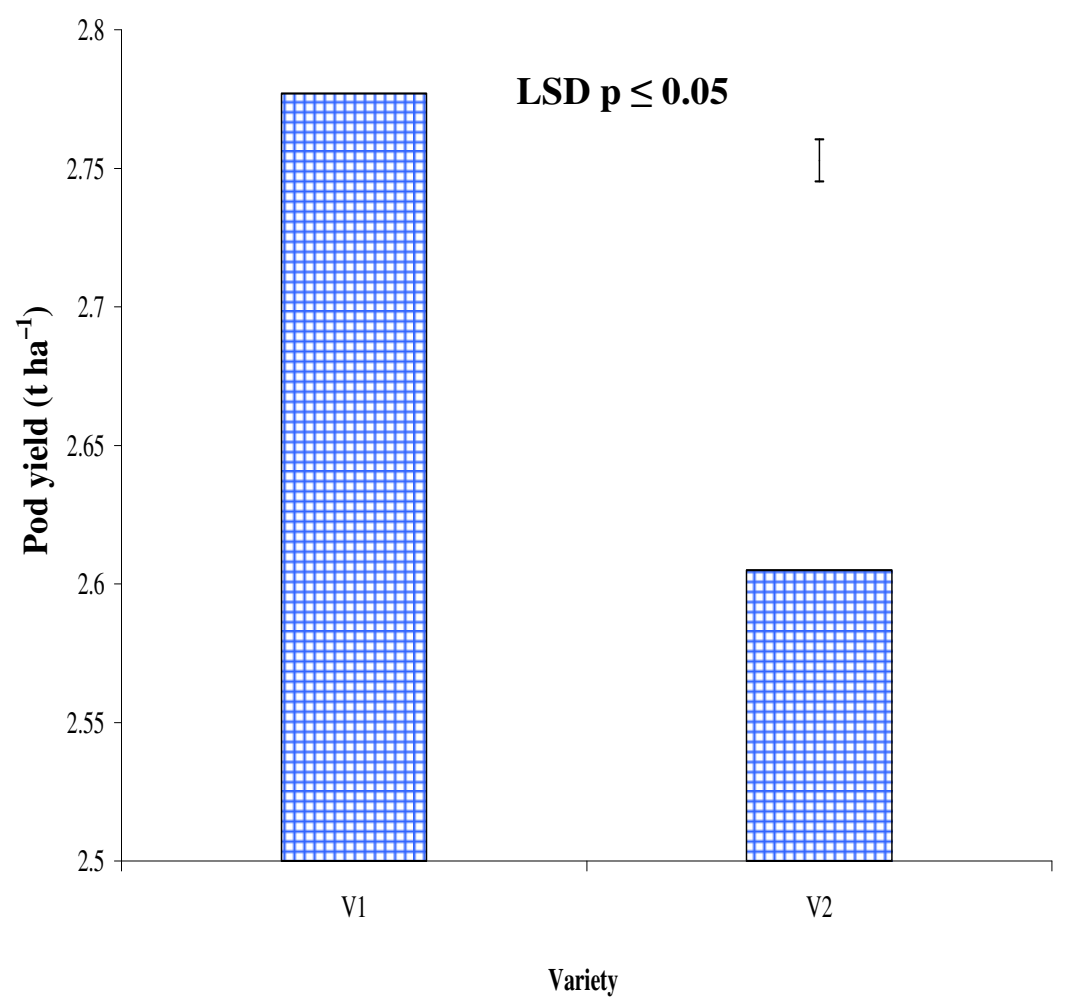

Fig. 5. Effect of variety on pod yield of groundnut $\mathrm{V}_{1}=$ BARI Cheenabadam- $8, \mathrm{~V}_{2}=$ Binacheenabadam -6 .

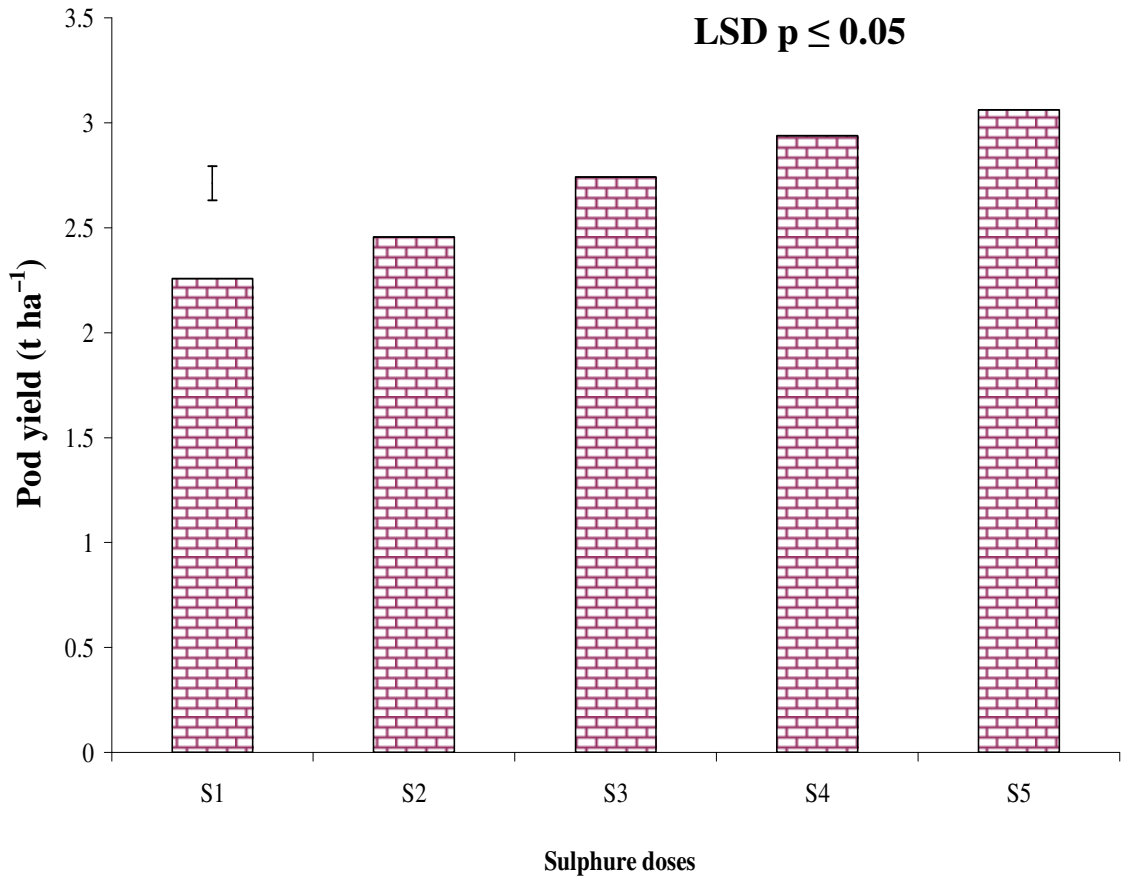

Fig. 6. Effect of sulphur on pod yield of groundnut

$\mathrm{S}_{1}=0 \mathrm{~kg} \mathrm{Sha}^{-1}, \mathrm{~S}_{2}=15 \mathrm{~kg} \mathrm{Sha}^{-1}, \mathrm{~S}_{3}=30 \mathrm{~kg} \mathrm{~S} \mathrm{ha}^{-1}, \mathrm{~S}_{4}=45 \mathrm{~kg} \mathrm{~S} \mathrm{ha}^{-1}$ and $\mathrm{S}_{5}=60 \mathrm{~kg} \mathrm{~S} \mathrm{ha}^{-1}$ 


\section{Stover yield}

The effect of variety on stover yield was significant (Table 1). Higher stover yield $\left(6.29 \mathrm{t} \mathrm{ha}^{-1}\right)$ was recorded from BARI Cheenabadam-8 than that of BINA Cheenabadam-6 $\left(6.08 \mathrm{t} \mathrm{ha}^{-1}\right)$. The effect of sulphur on stover yield was significant (Table 2). It was noted that stover yield increased progressively with increasing level of sulphur. Stover yield was the highest $(6.74$ $\mathrm{t} \mathrm{ha}^{-1}$ ) in $60 \mathrm{~kg} \mathrm{~S}^{-1}$ followed in-order by $\mathrm{S}_{4}, \mathrm{~S}_{3}$ and $\mathrm{S}_{2}$ $\left(6.48 \mathrm{tha}^{-1}, 6.36 \mathrm{tha}^{-1}\right.$ and $5.84 \mathrm{tha}^{-1}$, respectively) The improvement of dry matter was mainly responsible for the increased stover yield in $60 \mathrm{~kg} \mathrm{~S}^{-1}$. Interaction effect of variety and sulphur on stover yield was significant (Table 3). Stover yield was the highest $(6.84 \mathrm{t}$ $\left.\mathrm{ha}^{-1}\right)$ at $\mathrm{V}_{1} \times \mathrm{S}_{5}$ and the lowest $\left(5.28 \mathrm{t} \mathrm{ha}^{-1}\right)$ one was found at $\mathrm{V}_{2} \times \mathrm{S}_{1}$.

\section{Harvest index}

The effect of variety on harvest index was significant (Table 1). Higher harvest index (30.62\%) was recorded from BARI Cheenabadam-8 than that of BINA Cheenabadam-6 (30.01\%). The effect of sulphur on harvest index was significant (Table 2). Harvest index was the highest $(31.24 \%)$ in $60 \mathrm{~kg} \mathrm{~S} \mathrm{ha}^{-1}$ followed inorder by $\mathrm{S}_{4}, \mathrm{~S}_{3}$ and $\mathrm{S}_{2}(31.20 \%, 30.13 \%$ and $29.58 \%$, respectively). Interaction effect of variety and sulphur on harvest index was significant (Table 3). Harvest index was the highest $(31.37 \%)$ at $\mathrm{V}_{1} \times \mathrm{S}_{5}$ and the lowest (28.28\%) one was found at $V_{2} \times S_{1}$

\section{Conclusion}

The positive response between variety and sulphur application on yield components and yield of groundnut was noticed in this study. Leaf area index, total dry matter plant ${ }^{-1}$, number of primary and secondary branches was the highest variety BARI Cheenabadam- 8 and sulphur $60 \mathrm{~kg} \mathrm{ha}^{-1}$. Number of pegs, number of total pods plant $^{-1}$ were the highest in variety BARI Cheenabadam- 8 and sulphur $60 \mathrm{~kg} \mathrm{ha}^{-1}$ and was the lowest in variety BINA Cheenabadam- 6 and sulphur 0 $\mathrm{kg} \mathrm{ha}^{-1}$. Accordingly, 100-pods weight,100-seeds weight and shelling percentage were the highest for variety BARI Cheenabadam- 8 and sulphur $60 \mathrm{~kg} \mathrm{ha}^{-1}$. Pod yield, seed yield, stover yield, and harvest index were the highest in variety BARI Cheenabadam- 8 and sulphur $60 \mathrm{~kg} \mathrm{ha}^{-1}$ and were the lowest in variety BINA Cheenabadam-6 and sulphur $0 \mathrm{~kg} \mathrm{ha}{ }^{-1}$. So it can be concluded that variety BARI Cheenabadam- 8 fertilized with sulphur at the rate of $60 \mathrm{~kg} \mathrm{ha}^{-1}$ is a promising practice for the highest yield of groundnut.

\section{References}

Bandapadhyay, P., Samuni, R. C. and Bera, P. S., 1998. Performance of kharif groundnut cultivars with different sources of sulphur in West Bengal. Indian. Journal of Agriculture, 42 (3): 41-46.

Bhardwaj, S. P. and Pathak, A. N., 1987. Fruiting of groundnut (Arachis hypogaea L.) as affected by sulphur nutrition. Indian Journal of Agricultural Research, 21 (4): 175--179.

Chaubey, A. K., Singh, S. B. and Kaushik, M. K., 2000. Response of grpundnut to source and level of sulphur fertilization in mid western plains of Uttar Pradesh. Indian Journal of Agronomy, 45 (1): 166-169.

Colman, R., 1996. The importance of sulphur as a plant nutrient in world crop production. Soil Science, 101: 230-239. https://doi.org/10.1097/00010694-196604000-00002

Dimreej, S., Dwivedi, K. N. and Hari Ram. 1993. Effect of sulphur and phosphorus nutrition on yield attributes of groundnut (Arachis hypogaea L.). Indian Journal of Agronomy, 38: 327-328.

FAO and UNDP (Food and Agriculture Organization). 1988. Land Resources Appraisal of Bangladesh for Agricultural Development. Report 2. Agro- ecological Regions of Bangladesh. pp. 212-221.

Gomez, K. A. and Gomez, A. A., 1984. Statistical Procedure for Agricultural Research. Int. Rice Res. Inst., John Willey and Sons. New York, Chichester, Brisbane, Toronto, Singapore. pp. 139-240.

Mondal, M. R. I. and Wahhab, M. A., 2001. Production Technology of Oilseed Crops Oilseed Research Centre. BARI. Gazipur1701. p. 125.

Russel, D. F., 1986. MSTAT-C package programme. Crop and Soil Science, Department, Michigan State University, USA.

Sagare, B. N., Bhalkar, D, V. and Deshmukh, V. A., 1986. Studies on nodulation and nitrogen fixation by groundnut as affected by various levels of sulphur and phosphorus. PKV Research Journal, 10 (1): 10-15.

Singh, S., Kumur, Y., Gill, P. P., Singh, S. and Kumur, Y., 2003. Growth characteristics of summer groundnut as influenced by sulphur levels, irrigation schedules and organic manure. Annals of Biology, 19 (2): 135-139.

Thirumalaisami, K., Sathasivam, R. and Natarajaratnam., 1986. Effect of sulphur fertilization on nutrient content, dry matter production and yield of groundnut. Madras Agricultural Journal, 73(3): 151-154. 